\title{
PENGARUH KESIAPAN MENJADI ORANG TUA DAN POLA ASUH PSIKOSOSIAL TERHADAP PERKEMBANGAN SOSIAL ANAK
}

\author{
Yuli Dwi Setyowati ${ }^{1 *}$, Diah Krisnatuti ${ }^{2}$, Dwi Hastuti ${ }^{2}$ \\ ${ }^{1}$ Program Studi Ilmu Keluarga dan Perkembangan Anak, Sekolah Pascasarjana, Institut Pertanian Bogor, Bogor \\ 16680, Indonesia \\ ${ }^{2}$ Departemen IImu Keluarga dan Konsumen, Fakultas Ekologi Manusia, Institut Pertanian Bogor, Bogor 16680, \\ Indonesia \\ ")Email: yuisetyowati@gmail.com
}

\begin{abstract}
Abstrak
Tujuan penelitian ini adalah menganalisis pengaruh kesiapan menjadi orang tua dan pola asuh psikososial terhadap perkembangan sosial anak usia 2-3 tahun. Penelitian ini menggunakan desain cross sectional study dan retrospective study di Kelurahan Besar, Kecamatan Labuhan dan Kelurahan Kota Matsum, Kecamatan Medan Area, Kota Medan. Sebanyak 100 keluarga yang memiliki anak pertama usia 2-3 tahun kemudian dipilih dengan metode purposif sebagai responden. Instrumen HOME digunakan untuk mengukur stimulasi psikososial, instrumen Parenthood Readiness digunakan mengukur kesiapan menjadi orang tua sedangkan instrumen Vineland Social Maturity Scale digunakan mengukur perkembangan sosial anak. Data dianalisis menggunakan Partial Least Square (PLS). Kesiapan menjadi orang tua terkategori sedang dengan indeks rataan 72,1 11,1 . Hampir dua per tiga keluarga $(62,0 \%)$ memiliki stimulasi psikososial (HOME) yang rendah dengan indeks rataan $56,2 \pm 16,3$. Sebagian besar anak memiliki tingkat perkembangan sosial terkategori rendah dengan indeks ratan $56,5 \pm 14,9$. Semakin matang usia istri dan suami saat menikah maka akan semakin matang kesiapannya menjadi orang tua dan semakin baik pula stimulasi psikososial yang diberikan. Hal ini meningkatkan peluang perkembangan sosial anak untuk menjadi lebih baik.
\end{abstract}

Kata kunci: kesiapan menjadi orang tua, pola asuh psikososial, perkembangan sosial

\section{Effect of Parenthood Readiness and Psychosocial Parenting toward Social Development of Children}

\begin{abstract}
The purpose of this study was to analyze the effect of parenthood readiness and parenting psychosocial to social development in 2-3 years old. This study used cross sectional dan retrospective design in the Village Besar, Labuhan Subdistrict, and Village Medan Area, Kota Matsum Subdistrict, Medan City. One hundred families selected by purposive sampling child and mother as respondents. Data were analyzed using Partial Least Square (PLS). The questionnaire of Parenthood Readiness used for assessing readiness to become parenthood, HOME Inventory to assessing parenting psychosocial and Vineland Social Maturity used for Social Development in 2-3 years old. Parenthood readiness was categorized by the index average of $72,1 \pm 11,07$. Nearly two-thirds of families $(62,0 \%)$ have psychosocial parenting categorized amateurish with an index average $56,2 \pm 16,3$. Mostly of children have social development categorized less independent $(62,0 \%)$ with an index average $56,5 \pm 14,9$. The higher age of maternal and paternal, more ready to become parents and good in psychosocial parenting. These will increase opportunities for social development for children to become independent.
\end{abstract}

Key words: parenthood readiness, psychosocial parenting, social development

\section{PENDAHULUAN}

Kualitas sumber daya manusia dapat dicapai dengan memberikan solusi terhadap masalah tumbuh kembang anak di Indonesia. Hasil laporan riset kesehatan dasar (2013), menunjukkan bahwa 37 persen anak Indonesia mengalami keterlambatan tumbuh kembang yang disebabkan oleh rendahnya tingkat sosial-ekonomi masyarakat, pengasuhan orangtua yang kurang baik dan asupan makanan yang kurang (KEMENKES, 2013). Selanjutnya, menurut laporan hasil stimulasi deteksi dan intervensi tumbuh kembang (SDIDTK) Balita di Kota Medan tahun 2014 menunjukkan bahwa sebanyak $34 \%$ balita mengalami gangguan tumbuh kembang (Dinkes Kota Medan, 2015).

Masalah tumbuh dan kembang di Indonesia dapat disebabkan rendahnya pengetahuan orangtua dan tidak adanya persiapan khusus 
dari perempuan dan laki-laki untuk menjadi orangtua. Perempuan tidak memiliki cukup keahlian dan keterampilan untuk mengasuh anak akibat usia yang terlalu muda saat menikah. Ketidaksiapan perempuan berhubungan signifikan dengan pengalaman baru sebagai seorang ibu yang rendah pengetahuan, terlalu muda dan tidak memiliki pemahaman yang cukup terkait pemberian makan dan perkembangan anak (Kitano, 2016). Penelitian Tsania (2015) di daerah Jawa Barat juga menemukan bahwa, kesiapan perempuan untuk menghadapi perannya yang baru sebagai istri dan ibu memiliki hubungan yang signifikan dengan perkembangan anak di usia balita. Ibu yang mempersiapkan diri untuk bisa membesarkan anak akan meningkatkan kemampuannya dalam mengasuh anak.

Ayah dan ibu memiliki kewajiban untuk memenuhi kebutuhan anaknya yang meliputi, pengasuhan, agama, psikologi, makan, minum dan sebagainya (Puspitawati, 2013). Kualitas pengasuhan yang diberikan ibu sebagai pengasuh utama mempunyai peranan penting bagi perkembangan anak (Hastuti, Fiernanti \& Guhardja, 2011). Salah satu pengasuhan yang dilakukan ibu di rumah adalah pola asuh psikososial.

Pola asuh psikososial meliputi reaksi emosi, dorongan positif, suasana yang nyaman, kasih sayang yang ditunjukkan orang tua, sarana tumbuh kembang dan belajar (Bradley, Robert, \& Caldwell, 1981). Pemberian pengasuhan yang baik kepada anak, terutama pengasuhan psikososial berhubungan signifikan dengan karakteristik keluarga dan karakteristik anak yang terdiri atas lama pendidikan ibu dan usia anak. Pola asuh psikososial berupa pemberian stimulasi akan memengaruhi perkembangan anak (Hastuti, Fiernanti, \& Guhardja, 2011). Pola asuh dengan memberikan stimulus psikosoial kepada anak akan mampu meningkatkan perkembangan motorik, kognitif, sosial emosi dan moral/karakter pada anak (Hastuti, 2009). Hal ini menunjukkan bahwa peran ibu sebagai pengasuh utama mampu mempengaruhi tingkat perkembangan anak.

Peran orang tua sebagai pengasuh perlu
diperhatikan dengan baik untuk
mengoptimalkan perkembangan sosial anak.
Perkembangan sosial anak pada usia 2-3
tahun tergolong pada tahap autonomy vs
shame \& doubt (Erikson, 1950). ). Anak pada
masa ini bila sudah merasa mampu
menguasai anggota tubuhnya dapat
meimbulkan rasa otonomi, sebaliknya bila
lingkungan tidak memberi kepercayaan atau

terlalu banyak bertindak untuk anak akan menimbulkan rasa malu dan ragu-ragu. Pentingnya lingkungan sekitar anak dalam melatih rasa percaya diri dan sosial bisa dimulai dari lingkungan keluarga. Anak yang diberikan pola asuh dan stimulai psikososial yang baik akan berpengaruh positif terhadap perkembangan sosial-emosi anak (Hastuti \& Latifah, 2010).

Oleh karena itu, penelitian ini dianggap penting untuk dilakukan agar generasi muda, utamanya yang sedang mempersiapkan diri menjadi orang tua dapat lebih memahami akan pentingnya kesiapan menjadi orang tua dan pola asuh bagi perkembangan soisal anak. Tujuan dari penelitian ini adalah untuk menganalisis pengaruh karakteristik anak, karakteristik keluarga, kesiapan menjadi orang tua, dan pola asuh psikososial terhadap perkembangan sosial anak usia 2-3 tahun.

\section{METODE}

Penelitian dilakukan di Kelurahan Besar (Kecamatan Labuhan) dan di Kelurahan Kota Matsum (Kecamatan Medan Area) yang berada di Kota Medan, Sumatera Utara. Penelitian ini merupakan bagian dari suatu proyek penelitian Kajian Pola Pemberian ASI Dan Kaitannya Dengan Kesiapan Menjadi Orangtua Dan Dukungan Keluarga Dalam Upaya Mendukung Gerakan Minum ASI" di Kota Medan yang bekerjasama dengan Badan Koordinasi Keluarga Berencana Nasional (BKKBN) tahun 2016. Populasi penelitian ini adalah keluarga utuh yang memiliki anak usia 2-3 tahun dari ibu yang menikah muda dan dewasa. Pemilihan contoh penelitian dilakukan secara purposive, dengan pertimbangan (1) Ibu yang baru memiliki anak pertama usia 2-3 tahun; (2) anak laki-laki dan perempuan berusia 2-3 tahun (3) Berasal dari keluarga lengkap (utuh) dan (4) bersedia dijadikan responden. Responden dalam penelitian ini adalah 100 orang ibu dan 100 orang anak pertama usia 2-3 tahun. Responden penelitian ini adalah:

Metode yang digunakan dalam penelitian ini adalah kombinasi antara cross sectional study, yaitu penelitian yang dilakukan hanya pada satu waktu dan retrospective study (kesiapan menjadi orangtua), yaitu penggalian informasi di masa lalu. Data primer dalam penelitian ini terdiri dari: karakteristik keluarga (usia ayah dan ibu, besar keluarga, lama pendidikan ayah dan ibu, dan pendapatan per kapita); karakteristik anak (jenis kelamin dan usia); pola asuh psikososial dan perkembangan 
sosial anak. Data sekunder diperoleh dari Badan Pusat Statistik Kota medan (data jumlah anak usia balita), kecamatan dan kelurahan (data jumlah anak usia balita dalam satu kelurahan).

Data karakteristik keluarga yakni pendapatan orang tua dikonversikan menjadi pendapatan per kapita yang kemudian dikategorikan menggunakan indikator garis kemiskinan BPS Kota Medan (2016). Sistem skoring yang dilakukan untuk kesiapan menjadi orang tua, pola asuh psikososial dan perkembangan sosial anak menggunakan rumus indeks. Pengkategorian variabel kesiapan menjadi orang tua, pola asuh psikososial dan perkembangan sosial menggunakan cut off point tinggi/baik $(80,0-100,0)$, sedang $(60,0$ $80,0)$ dan rendah $(0,0-60,0)$.

Kuisioner yang dipakai dalam penelitian ini adalah Readiness of Parenthood (modifikasi dari Brisbane, 2010) untuk menilai kesiapan ibu menjadi orang tua dengan reliabilitas sebesar 0,732. Kuisioner tersebut terdiri dari 25 pertanyaan dan menggunakan skala Guttman meliputi $\mathrm{Ya}=1$ dan Tidak=0. HOME Inventory (Bradley \& Caldwell, 1984) untuk menilai stimulasi psikososial didalam keluarga dengan reliabilitas sebesar 0,878 , terdiri dari 45 pertanyaan dan menggunakan skala Guttman meliputi $\mathrm{Ya}=1$ dan Tidak $=0$. Vineland Sosial Maturity Scale (Doll, 1965) untuk mengukur perkembangan sosial anak usia 2-3 tahun dengan reliabilitas sebesar 0,853 , terdiri dari 10 pertanyaan dengan skala likert $0=$ tidak bisa, $1=$ bisa tapi dibantu, $2=$ bisa sendiri.

Analisis pengaruh dilakukan dengan menggunakan Partial Least Square yang diolah menggunakan SmartPLS 3,0. PLS juga dapat digunakan untuk mengkonfirmasi teori dan menjelaskan ada atau tidaknya hubungan antar variabel laten. Semua indikator pada model penelitian ini pada dasarnya bersifat reflektif sehingga perlu dilakukan analisis outer model dengan menggunakan lima kriteria yakni convergent validity, composite reliability, average variance extracted (AVE), akar kuadrat AVE dan Cross Loading (Ghazali, 2015).

\section{HASIL}

\section{Karakteristik Anak dan Keluarga}

Usia anak laki-laki dan perempuan yang menjadi responden dalam penelitian ini berkisar antara 24 bulan sampai dengan 36 bulan. Jumlah anak laki-laki sebesar 44 orang dan perempuan 56 orang. Anak usia dua tahun berjumlah 78 orang dan tiga tahun berjumlah 22 orang.

Rata-rata usia menikah ibu $(22,1 \pm 2,9)$ dan ayah $(26,0 \pm 3,8)$ berada pada kategori dewasa awal yaitu 22 tahun dan 26 tahun, dengan rentang usia mulai dari 16 tahun hingga 40 tahun. Selanjutnya usia ibu $(26,2 \pm 3,4)$ dan ayah $(30,2 \pm 4,4)$ saat pengambilan data berada pada kategori dewasa awal, dengan rentang usia 19 hingga 43 tahun. Kemudian, lama pendidikan ayah $(11,5 \pm 2,0)$ dan pendidikan ibu $(11,4 \pm 2,5)$ tergolong sedang dengan rata-rata keduanya selama sebelas tahun. Hal tersebut menunjukkan bahwa rata-rata pendidikan orang tua tidak lulus Sekolah Menengah Atas (SMA).

Rata-rata tingkat pendapatan per kapita keluarga adalah $\mathrm{Rp} 762.185 \pm 363.886$. Berdasarkan batas garis kemiskinanya, keluarga yang termasuk dalam kriteria miskin adalah keluarga dengan pendapatan per kapita per bulannya kurang dari Rp 401.417. Diketahui sebanyak 16,0 persen dari total responden masih tergolong miskin, sebagian besar berada di kelurahan Besar, Kecamatan Labuhan. Temuan ini menunjukkan bahwa keluarga di Kecamatan Labuhan dalam penelitian ini mempunyai status sosial ekonomi rendah.

\section{Kesiapan Menjadi Orang tua}

Kesiapan menjadi orang tua teridiri dari enam dimensi, yakni kesiapan emosi, finansial, fisik, sosial, menejemen dan hubungan antar orang tua. Hasil penelitian menunjukkan bahwa rataan skor kesiapan menjadi orang tua sebesar 72,1 dengan standar deviasi sebesar 11,1. Kesiapan finansial memiliki skor rataan terendah $(53,1)$ dibandingkan dimensi lainnya. Rendahnya kesiapan finansial ibu dan pasangan terlihat dari hasil analisis pertanyaan. Hasil menunjukkan bahwa lebih dari setengah $(57 \%)$ responden menyatakan bahwa mereka belum memiliki pekerjaan tetap sebelum anak lahir. Responden (70\%) mengaku bahwa mereka menikah tanpa memiliki tabungan atau asuransi finansial untuk biaya sekolah maupun kesehatan anak. Berdasarkan hasil wawancara mendalam menunjukkan bahwa banyak dari ibu yang masih menumpang tinggal di tempat orang tua mereka dari awal menikah hingga sekarang memiliki anak, sehingga mereka masih belum mandiri dan belum mampu melakukan perencanaan keuangan keluarga yang baik. 
Tabel 1 Sebaran responden berdasarkan kesiapan menjadi orang tua (\%)

\begin{tabular}{lcccc}
\hline \multicolumn{1}{c}{ Dimensi } & \multicolumn{3}{c}{ Kategori } & $\begin{array}{c}\text { Rata-rata } \\
\text { SD }\end{array}$ \\
\hline Emosi & 8,0 & 34,0 & 58,0 & $72,9 \pm 17,6$ \\
Finansial & 77,0 & 13,0 & 10,0 & $53,1 \pm 14,8$ \\
Fisik & 35,0 & 28,0 & 37,0 & $78,3 \pm 21,1$ \\
Sosial & 18,0 & 46,0 & 36,0 & $66,2 \pm 18,3$ \\
Menejemen & 37,0 & 40,0 & 23,0 & $69,9 \pm 20,6$ \\
Hubungan & 4,0 & 32,0 & 64,0 & $88,6 \pm 17,8$ \\
Total & 1,0 & 31,0 & 68,0 & $72,1 \pm 11,1$ \\
Kesiapan & \multicolumn{5}{l}{ Keterangan: R=Rendah, S=Sedang, T=Tinggi }
\end{tabular}

Skor kesiapan tertinggi terlihat pada kestabilan hubungan antarpasangan $(88,6)$. Kestabilan hubungan antara pasangan mengartikan adanya dukungan dan kasih sayang antar lakilaki dan perempuan. Dukungan yang diberikan adalah suami menemani saat memeriksakan kehamilan, menemani istri melahirkan dan memberikan kasih sayang setiap saat kepada pasangan.

Hubungan yang baik antar pasangan akan menurunkan resiko stress istri dan agar mampu saling mendukung menjadi orang tua baru. Usia ibu yang masih tergolong muda membutuhkan perhatian dan dukungan khusus yang diberikan suami. Jumlah ibu yang memiliki kesiapan fisik yang tinggi sebanyak 37,0 persen dan rendah 35,0 persen. Meskipun demikian, skor rataan dimensi $(78,3)$ kesiapan fisik tertinggi kedua diantara dimensi lainnya. Hal ini berarti ibu sudah cukup baik secara fisik atau fisiologi tubuhnya. Sebanyak 31,0 persen ibu, memiliki riwayat penyakit sebelum memiliki anak dan juga perilaku tidak sehat lainnya. Sebanyak sepuluh orang ibu terbiasa merokok dan dua orang diantaranya disertai dengan asma. Beberapa ibu juga mengaku menderita tekanan darah rendah (19 orang) dan lima diantaranya menderita anemia. Contoh lain juga mengaku menderita hipertensi (tekanan darah tinggi), pengalaman masalah kehamilan (keguguran) dan obesitas (kegemukan).

Rata-rata kesiapan menejemen ibu $(69,9)$ tergolong sedang. Mayoritas ibu mengaku masih belum terbiasa mengatur keuangan dan kebutuhan orang lain selain dirinya sendiri. Mereka belajar mengatur keuangan setelah menikah tanpa ada perencanaan terlebih dahulu. Responden mengaku bahwa uang yang diterima dari pengahasilan suami hanya cukup untuk kebutuhan pokok saja, sehingga tidak perlu ada keahlian khusus. Hal ini berbeda dengan Brisbane (2010), yang mengatakan bahwa seorang perempuan dan laki-laki perlu menyiapkan keahlian khusus untuk mengatur sumberdaya yang ada di keluarga. Sumberdaya di dalam keluarga ada dua jenis, yang bisa diukur (tangible) seperti uang, emas, rumah, kendaraan dan yang tidak bisa diukur (intangible) seperti waktu, peran dan fungsi pengasuhan serta anggota keluarga. Sama halnya dengan kesiapan menejemen, kesiapan sosial ibu juga tergolong sedang $(66,2)$. Hal ini menunjukkan bahwa sebelum memiliki anak ibu sudah melakukan komunikasi dan kegiatan sosial yang baik kepada dirinya sendiri dan orang disekitarnya. lbu tidak menutup diri dan mau bersosialisasi dengan lingkungannya.

\section{Pola Asuh Psikososial}

Dimensi pola asuh psikososial dalam penelitian ini dinilai dari aspek tanggap rasa dan kata, penerimaan terhadap perilaku anak, pengorganisasian lingkungan anak, penyediaan (mainan untuk anak), keterlibatan ibu terhadap anak dan kesempatan variasi asuhan anak. Hasil penelitian menunjukkan bahwa penyediaan mainan untuk anak memiliki rata-rata terendah $(47,4)$ diantara dimensi lainnya. Sebagian besar ibu $(70,0 \%)$ tidak menyediakan berbagai macam mainan edukatif dirumah seperti mobil-mobilan, boneka, buku, balok dan kursi beroda/sepeda. Ibu mengaku kurang memberikan alat-alat dan stimulasi permainan yang sesuai dengan usia anak. Anak-anak hanya dibiarkan bermain diluar bersama dengan anak-anak lainnya dan menonton televisi di rumah untuk menghabiskan waktunya sehari-hari. Beberapa anak juga diberikan smartphone untuk bermain sendiri selama di rumah. Kurang aktifnya orang tua dalam memberikan stimulasi kepada anak akan berisiko dalam penurunan perkembangan anak. Kesempatan variasi pengasuhan anak memiliki skor terendah $(51,2)$ kedua setelah penyediaan mainan anak. Lebih dari setengah ibu mengaku bahwa suami selalu ikut mengasuh anak setiap hari, tetapi variasi stimulasi yang diberikan ibu masih kurang. Ibu mengaku tidak pernah bercerita/mendongeng secara khusus kepada anaknya dan tidak pernah diajak menginap di rumah saudaranya. Kurangnya pemberian pengasuhan dengan bercerita disebabkan mayoritas ibu tidak memiliki buku cerita yang bisa diperdengarkan kepada anak.

Berbeda dengan variasi pengasuhan yang diterima anak, dimensi tanggap rasa dan kata memiliki rataan dengan nilai tertinggi $(68,5)$ dibanding dimensi lainnya. Sebagian besar ibu sudah memberikan perhatian, pujian, mencium 
anaknya dan pernyataan langsung kepada anak selama proses pengambilan data. Dilihat dari total hasil penelitian, sebagian besar pola asuh psikososial di Kota Medan termasuk dalam kategori rendah $(62,0 \%)$.

\section{Perkembangan Sosial Anak}

Dimensi perkembangan sosial anak dalam penelitian ini dinilai dari aspek Self Help General, Self Help Eating, Self Help Dressing, Occupation dan Communication. Hasil penelitian secara keseluruhan menunjukkan bahwa rata-rata skor perkembangan sosial anak tergolong rendah $(56,5)$. Kategori perkembangan yang rendah lebih banyak ditemukan di daerah pinggiran kota $(89,6 \%)$ dan hanya sepersepuluh (15,4\%) anak yang memiliki perkembangan rendah di daerah tengah kota. Rendahnya tingkat perkembangan sosial anak menunjukkan bahwa anak masih belum mampu melakukan kegiatan untuk dirinya sendiri. Kurangnya stimulasi yang diberikan ibu membuat anak kurang terampil untuk melakukan pekerjaan untuk dirinya sendiri. Tingkat perkembangan sosial anak yang tinggi lebih banyak ditemukan di daerah tengah kota dibandingkan daerah pinggiran. Sebaran data perkembangan sosial anak berdasarkan dimensinya dapat dilihat pada Tabel 3.

Tabel 2 Sebaran responden berdasarkan pola asuh psikososial (\%)

\begin{tabular}{|c|c|c|c|c|}
\hline \multirow{2}{*}{ Dimensi } & \multicolumn{3}{|c|}{ Kategori } & \multirow{2}{*}{$\begin{array}{l}\text { Rataan } \\
\pm \text { stdev }\end{array}$} \\
\hline & $\mathrm{R}$ & $S$ & $\mathrm{~T}$ & \\
\hline $\begin{array}{l}\text { Tanggap } \\
\text { rasa dan } \\
\text { kata }\end{array}$ & 39,0 & 22,0 & 39,0 & $\begin{array}{c}68,5 \pm \\
20,4\end{array}$ \\
\hline $\begin{array}{l}\text { Penerimaan } \\
\text { terhadap } \\
\text { perilaku } \\
\text { anak }\end{array}$ & 44,0 & 39,0 & 17,0 & $\begin{array}{c}55,0 \pm \\
26,5\end{array}$ \\
\hline $\begin{array}{l}\text { Peorganisasi } \\
\text { an } \\
\text { lingkungan } \\
\text { anak }\end{array}$ & 40,5 & 24,5 & 35,0 & $\begin{array}{c}54,3 \pm \\
23,0\end{array}$ \\
\hline $\begin{array}{l}\text { Penyediaan } \\
\text { : maianan } \\
\text { untuk anak }\end{array}$ & 70,0 & 12,0 & 18,0 & $\begin{array}{c}47,4 \pm \\
26,2\end{array}$ \\
\hline $\begin{array}{l}\text { Keterlibatan } \\
\text { ibu terhadap } \\
\text { anak }\end{array}$ & 66,0 & 14,0 & 20,0 & $\begin{array}{c}66,3 \pm \\
33,8\end{array}$ \\
\hline $\begin{array}{l}\text { Kesempatan } \\
\text { variasi } \\
\text { asuhan anak }\end{array}$ & 53,0 & 18,0 & 29,0 & $\begin{array}{c}51,2 \pm \\
27,2\end{array}$ \\
\hline $\begin{array}{l}\text { Total pola } \\
\text { asuh } \\
\text { psikososial }\end{array}$ & 62,0 & 29,0 & 9,0 & $\begin{array}{c}57,6 \pm \\
15,7\end{array}$ \\
\hline
\end{tabular}

Tabel 3 Sebaran responden berdasarkan perkembangan sosial anak (\%)

\begin{tabular}{lcccc}
\hline \multirow{1}{*}{ Dimensi } & \multicolumn{3}{c}{ Kategori } & Rataan \pm \\
\cline { 2 - 4 } & $\mathrm{R}$ & $\mathrm{S}$ & $\mathrm{T}$ & stdev \\
\hline $\begin{array}{l}\text { Self Help } \\
\text { General }\end{array}$ & 25,0 & 28,0 & 47,0 & $74,2 \pm 22,2$ \\
$\begin{array}{l}\text { Self Help Eating } \\
\text { Self Help }\end{array}$ & 52,0 & 19,0 & 29,0 & $60,3 \pm 25,8$ \\
Dressing & 46,0 & 16,0 & 38,0 & \\
$\begin{array}{l}\text { Occupation } \\
\text { Communication }\end{array}$ & 68,0 & 22,0 & 10,0 & $45,8 \pm 19,8$ \\
$\begin{array}{l}\text { Total } \\
\text { perkembangan } \\
\text { sosial }\end{array}$ & 35,0 & 0,0 & 9,0 & $31,3 \pm 33,6$ \\
Keterangan: R=Rendah, S=Sedang, T=Tinggi & 26,0 & $56,5 \pm 14,9$ \\
& & & &
\end{tabular}

Skor rata-rata yang tertinggi berada pada dimensi self help general atau kemandirian umum $(74,2)$. Kemandirian umum merupakan kemampuan dan keinginan anak untuk melakukan segala sesuatu dengan sendiri. Kemampuan ini menjadikan anak dapat menolong dirinya sendiri dalam melakukan aktivitas sehari-hari sesuai tahap perkembangannya. Kemampuan anak dalam menolong dirinya sendiri tersebut merupakan kemampuan dasar anak untuk dapat mandiri. Kemandirian umum anak usia 2-3 tahun adalah naik dan turun tangga sendiri serta pergi ke kamar mandi sendiri. Kemandirian umum anak dilihat dari rata-ratanya dapat dikategorikan dalam kategori cukup mandiri. Sebanyak 47,0 persen anak sudah mampu untuk pergi ke toilet dan naik turun tangga tanpa dibantu orang lain. Sebagian besar anak sudah mampu untuk pergi ketoilet dan naik turun tangga tanpa dibantu orang lain. Meskipun demikian, masih terdapat beberapa anak yang dibantu untuk pergi ke toilet oleh pengasuhnya.

Self help eating adalah kemampuan anak untuk menolong diri sendiri dalam hal makan. Kemampuan anak usia 2-3 tahun dalam selfhelp eating adalah mampu mengambil makanan sendiri tanpa bantuan dan anak dapat memakai sendok atau garpu saat makan. Hasil penelitian menunjukkan bahwa rata-rata kemampuan anak dalam hal makan tergolong dalam kategori cukup mandiri $(60,3 \%)$. Tidak semua anak dalam penelitian ini mampu memakai garpu atau sendok untuk makan. Anak masih dibantu oleh pengasuh untuk keperluan makannya setiap hari. Ibu mengaku bahwa anak-anak mereka tidak dibiasakan untuk makan sendiri. Mereka lebih memilih menyuapi anak-anak mereka dikarenakan waktu yang relatif lebih singkat dan tidak membuat membuat lingkungan sekitarnya kotor. Meskipun demikian, banyak 
anak yang sudah mampu mengambilkan minuman/makananya sendiri tanpa dibantu orang lain.

Self-help dressing merupakan kemampuan anak menolong dirinya sendiri dalam hal berpakaian yakni mampu berpakaian sendiri. Kemampuan anak usia 2-3 tahun adalah membuka dan memakai kembali bajunya sendiri. Hasil penelitian menunjukkan bahwa kemampuan anak untuk berpakaian sendiri tergolong dalam kategori cukup bisa $(70,0 \%)$. Masih ada anak yang kurang bisa memakai dan membuka pakaiannya sendiri. Sebagian besar anak masih membutuhkan bantuan orang lain dalam memakaikan baju, tetapi bisa melepaskan pakaiannya sendiri. Ibu mengaku bahwa anak-anak mereka jarang diajarkan memakai pakaian sendiri. Mereka merasa bahwa anak usia 2-3 tahun masih kecil dan belum mampu diajarkan memakai pakaian sendiri. Meskipun demikian, sebagian besar anak sudah mampu untuk melepaskan pakaiannya sendiri.

Occupation atau task merupakan kemampuan anak untuk melakukan pekerjaan untuk dirinya sendiri untuk mencapai tujuan yang diinginkan. Kemampuan occupation anak usia 2-3 tahun adalah memakai gunting untuk memotong kertas dengan lurus dan menyusun balok atau puzzle dan menyelesaikannya sendiri Dimensi occupation masih tergolong dalam kategori rendah atau masih butuh bantuan $(45,8)$. Sebagain besar anak masih belum mampu untuk menggunakan gunting untuk memotong kertas secara lurus. Awal diberikan gunting anak merasa senang dan ingin segera memakai gunting tersebut. lbu mengaku bahwa anak mereka belum pernah memakai gunting sendiri di rumah. lbu beranggapan bahwa gunting merupakan benda tajam yang berbahaya jika dipakai anak. Sebenarnya, benda ini sudah boleh dipakai oleh anak secara mandiri dengan pemantauan orang dewasa. Meskipun demikian, berdasarkan hasil penelitian banyak anak yang sudah mampu menyusun balok atau puzzle secara mandiri tanpa bantuan orang lain.

Communication merupakan kemampuan anak dalam berkomunikasi seperti berbicara, tertawa dan menggunakan simbol-simbol sederhana, seperti menceritakan kembali dengan menghubungkan setiap ceritanya dengan baik. Kemampuan komunikasi yang dapat dilakukan oleh anak usia 2-3 tahun adalah menghubungkan kejadian yang dialaminya menjadi sebuah cerita dan meminta untuk makan secara sederhana. Sebagian besar anak sudah bisa meminta minum ketika haus, dapat meminta makan ketika lapar tetapi masih kurang bisa menghubungkan cerita secara sederhana. Anak-anak masih dibantu untuk menghubungkan bagian-bagian cerita yang dialaminya dan tidak secara mandiri diutarakannya. Komunikasi pada anak yang tinggal di daerah pinggiran masih kurang bisa untuk bercerita dan meminta untuk makan/minum. Mereka kurang mendapatkan stimulasi sosial dari ibu disebabkan oleh banyak waktu yang dihabiskan anak dengan menonton televisi di rumahnya. Perkembangan sosial anak dimensi komunikasi di Kota Medan memiliki skor rata-rata terendah $(31,3)$ dibandingkan dengan dimensi lainnya. Pendampingan pengasuh terutama ibu untuk melatih komunikasi anak sangat penting dilakukan, salah satunya adalah bercerita dongeng sebelum tidur dan menceritakan kembali pengalaman anak sebelumnya.

\section{Pengaruh usia menikah orang tua, karakteristik keluarga, kesiapan menjadi orang tua, pola asuh psikososial terhadap perkembangan sosial}

Uji pengaruh dilakukan dengan menggunakan metode Sem-Parsial untuk menganalisis adanya pengaruh karakteristik orang tua sebelum menikah, karakteristik keluarga, kesiapan menjadi orang tua terhadap pola asuh psikososial yang diberikan (Gambar 1).

Berdasarkan hasil analisis yang tersaji pada Tabel 4, terdapat pengaruh yang positif pada karakteristik sebelum menikah, karakteristik keluarga, kesiapan menjadi orang tua, pola asuh psikososial terhadap perkembangan sosial anak. Persentase pengaruh variabelvariabel tersebut terhadap perkembangan sosial anak adalah 21,7 persen (Gambar 1) dan sisa persentasi 78,3 persen lainnya dipengaruhi oleh variabel lain yang tidak diteliti di dalam penelitian ini.

\begin{tabular}{lccc} 
Tabel 4 & \multicolumn{2}{c}{$\begin{array}{c}\text { Pengaruh } \\
\text { perkembangan sosial }\end{array}$} & \multicolumn{2}{c}{ variabel } & terhadap \\
\hline \multicolumn{1}{c}{ Variabel } & \multicolumn{2}{c}{ Perkembangan Sosial } \\
\cline { 2 - 4 } & $\begin{array}{l}\text { Direct } \\
\text { effect }\end{array}$ & $\begin{array}{l}\text { Indirect } \\
\text { effect }\end{array}$ & $\begin{array}{c}\text { Total } \\
\text { effect }\end{array}$ \\
\hline $\begin{array}{l}\text { Karakteristik } \\
\text { sebelum menikah }\end{array}$ & 0,149 & 0,033 & 0,182 \\
$\begin{array}{l}\text { Karakteristik } \\
\text { keluarga }\end{array}$ & 0,286 & 0,142 & 0,428 \\
$\begin{array}{l}\text { Umur anak } \\
\begin{array}{l}\text { Kesiapan menjadi } \\
\text { orang tua }\end{array}\end{array}$ & $-0,025$ & - & $-0,025$ \\
$\begin{array}{l}\text { Pola asuh } \\
\text { psikososial }\end{array}$ & 0,187 & 0,003 & 0,124 \\
\hline
\end{tabular}




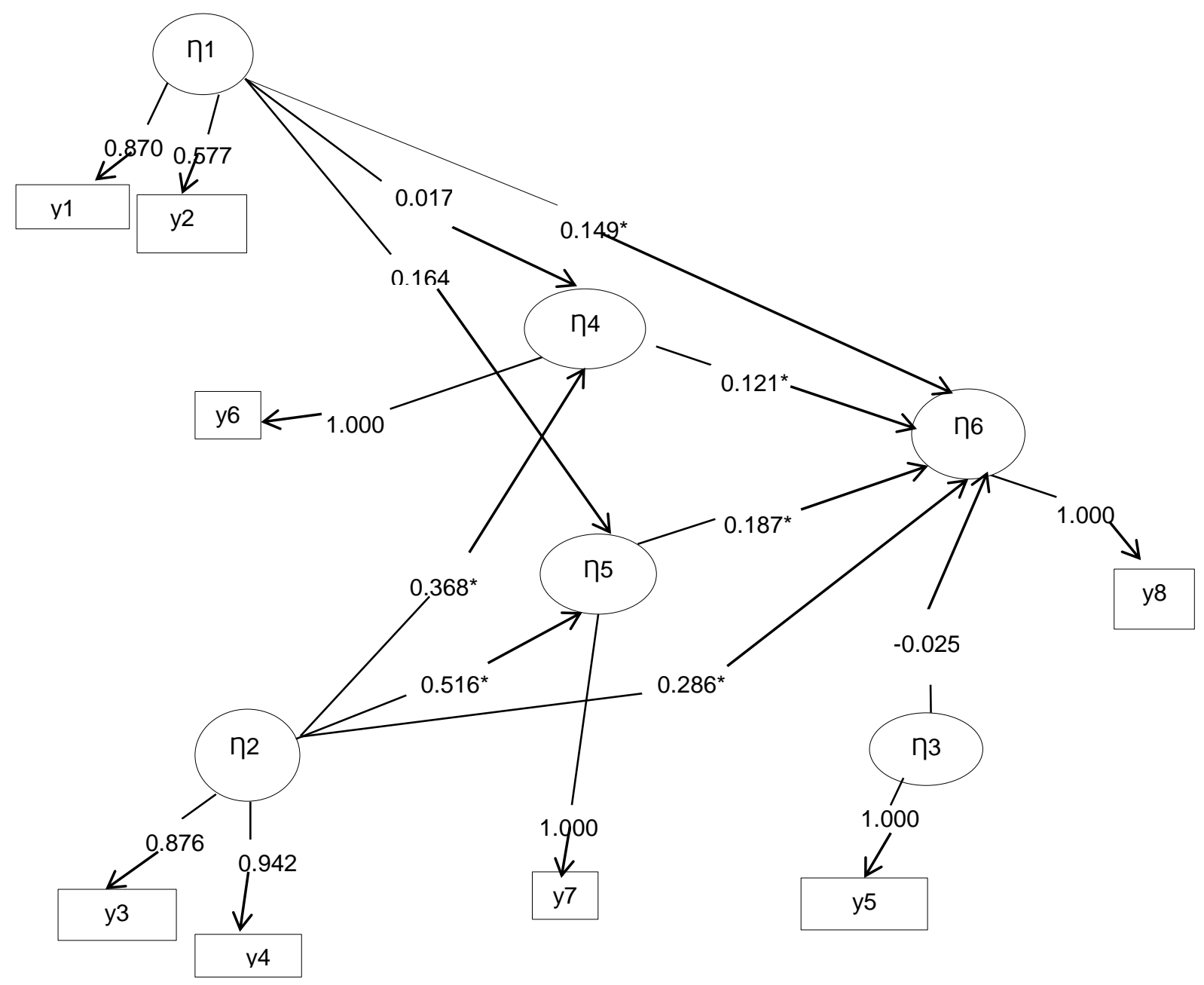

Keterangan: $\eta 1=$ karakteristik sebelum menikah; $\eta 2=$ Karakteristik keluarga; $\eta 3=u s i a$ anak; $\eta 4=$ =esiapan menjadi orangtua; $\eta 5=$ pola asuh; $\eta 6=$ perkembangan sosial; $y 1=u$ sia ayah saat menikah; y2=usia ibu saat menikah; $y 3=$ tingkat pendidikan ibu; y4=tingkat pendidikan ayah; y5=usia anak; y6=indeks kesiapan untuk menjadi orangtua; $y 7=$ indeks pola asuh psikososial; y8=indeks perkembangan sosial

\section{Gambar 1 Skema pengaruh variabel menggunakan Smart PLS}

Terlihat pada Gambar 1, terdapat pengaruh langsung antara karakteristik sebelum menikah $(\beta=0,149, t=1,989)$, karakteristik keluarga $(\beta=$ $0,286, t=2,672)$, kesiapan menjadi orangtua $(\beta=0,121, t=1,970)$, pola asuh psikososial $(\beta=$ $0,187, \mathrm{t}=2,043)$ terhadap perkembangan sosial anak. Hal ini mengindikasikan bahwa anak yang berasal dari keluarga dengan ibu dan ayah yang menikah di usia yang lebih matang, orang tua yang memiliki tingkat pendidikan yang tinggi, kesiapan ibu dan ayah untuk menjadi orang tua serta memberikan pola asuh psikososial yang baik akan meningkatkan perkembangan sosial anak kearah yang lebih mandiri dibandingkan dengan orang tua yang menikah muda, pendidikan orang tua rendah, tidak siap untuk menjadi orang tua, dan pola asuh psikososial yang diberikan rendah. Karakteristik keluarga (pendidikan ayah dan ibu) memiliki pengaruh tidak langsung positif signifikan $(\beta=0,142, \mathrm{t}=$ $1,986)$ terhadap perkembangan sosial anak. Hal ini berarti karakteristik keluarga (pendidikan ayah dan pendidikan ibu) memengaruhi perkembangan sosial anak secara tidak langsung melewati variabel kesiapan menjadi orang tua dan pola asuh psikososial.

\section{PEMBAHASAN}

Usia anak laki-laki dan perempuan ini berada pada rentang usia 2 hingga 3 tahun yang berada pada tahapan autonomy vs shame \& doubt (Santrock, 2007). Pengalamanpengalaman yang dialami anak pada rentang usia 2-3 tahun akan menentukan kemampuan anak dikemudian hari. Anak yang sudah merasa mampu menguasai anggota tubuhnya dapat menimbulkan rasa otonomi, sebaliknya 
bila lingkungan tidak memberi kepercayaan atau terlalu banyak bertindak untuk anak akan menimbulkan rasa malu dan ragu-ragu (Erikson, 1950).

Rata-rata usia orangtua saat menikah berada pada kategori dewasa muda dan usia orangtua saat ini berada pada rentang usia dewasa madya. Usia ibu yang muda saat menikah menunjukkan rendahnya kemampuan mengasuh. Ibu tidak mampu mengatur dan melakukan pengasuhan dalam pemberian makan dan afeksi kepada anak di usia bayi hingga pra-sekolah (Smith, 2012). Terbentuknya perilaku dan kualitas tumbuh kembang anak dapat dipengaruhi oleh kesiapan perempuan sebelum menikah yang akan menentukan siap atau tidaknya ibu untuk menjadi orang tua (Tsania, Sunarti, \& Krisnatuti, 2015). Perempuan sebelum menikah berperan sebagai seorang anak dari orang tuanya dan juga sebagai orang dewasa. Menginjak usia dewasa, perempuan akan mulai mempersiapkan dirinya kejenjang peran selanjutnya sebagai seorang ibu. Persiapan yang harus dilakukan oleh perempuan diantaranya adalah kematangan emosi, kesiapan keuangan/finansial, kesiapan fisik/fisiologis, kesiapan sosial, kemampuan untuk mengatur sumberdaya keluarga/menejemen dan kestabilan hubungan diantara pasangan (Badgar, 2005; Brisbane, 2010).

Kematangan emosi yang perlu dimiliki perempuan adalah mampu menahan emosi dalam keadaan tertekan dan tanggung jawab tanpa mengharapkan imbalan. Selanjutnya kesiapan finansial dan menejemen diperlukan untuk memenuhi segala kebutuhan yang diperlukan oleh anak dan kemampuan untuk mengatur semua kebutuhan tersebut, baik untuk diri sendiri maupun untuk anggota keluarga lainnya. Sedangkan kesiapan fisik yang diperlukan oleh seorang perempuan meliputi cukup usia saat menikah, tidak memiliki riwayat penyakit yang membayahakan, tidak memiliki kebiasaan merokok dan alkohol (Carrol, 2009; Brisbane, 2010). Ibu yang memiliki riwayat kesehatan (kesiapan fisik) memiliki pengaruh yang signifikan terhadap pertambahan berat badan anak di usia 2-3,5 tahun (Linabery et al., 2012).

Kesiapan sosial meliputi kebiasaan perempuan untuk mencari informasi untuk dirinya sendiri dan orang lain, mau ikut melakukan kegiatan sosial dan tidak menutup diri dengan lingkungan sekitar. Terakhir yang diperlukan oleh seorang perempuan adalah adanya dukungan pasangan bagi perempuan untuk melewati tahapan dalam keluarga dan komunikasi yang baik antar pasangan (Brisbane, 2010). Pentingnya kesiapan perempuan untuk menjadi ibu akan mengurangi resiko kesehatan yang dialami ibu. lbu yang memiliki riwayat penyakit sebelum memiliki anak akan meningkat resiko anak terlahir prematur atau meningkatkan resiko penyakit degeneratif (Brisbane, 2010).

Rata-rata usia ibu tergolong dewasa muda saat menikah dengan status pendidikan yang rendah memiliki pengaruh yang signifikan terhadap kesiapan menjadi orang tua. Hasil penelitian Augustine et al. (2015) menyatakan bahwa tingkat pendidikan ibu yang tinggi berpengaruh terhadap kemampuan berbahasa dan intelektualnya. Semakin matang usia dan tingkat pendidikan ibu yang tinggi akan meningkatkan kemampuan kognitif dan sosial anak di pre-school. Kemampuan sosial anak salah satunya adalah kemampuan untuk menolong dirinya sendiri atau disebut dengan perkembangan sosial.

Hasil penelitian Black et al. (2016) menyatakan bahwa seorang ibu yang melahirkan anak pertama kali berisiko lebih tinggi lima persen kalinya menjadi obesitas, tujuh persen kali lebih tinggi meningkatkan tekanan darah dan tiga persen kali lebih rendah kondisi fisik dan juga kesehatan mentalnya. Penyebabnya adalah ibu belum mampu mengontrol emosi saat mengasuh anak dan tidak memiliki waktu untuk dapat melakukan olahraga. Saat kelahiran anak pertama ibu merasakan kebahagiaan yang tinggi namun tidak beriringan dengan menejemen stress yang dialaminya.

Hasil penelitian Ashrafun (2016) menunjukan bahwa di masyarakat marginal Bangladesh perempuan dan laki-laki memilih untuk segera menikah disebabkan rendahnya tingkat pendidikan ibu dan semakin rendahnya jarak usia antar suami istri maka pengambilan keputusan bersama juga semakin baik. Usia menikah ibu yang lebih muda kurang mampu memberikan pengasuhan yang baik. lbu yang mempersiapkan dirinya untuk menjadi orangtua juga ditentukan oleh kesiapan sosial, finansial dan pengalaman yang baik dalam mengurus anak (Biktagiroval \& Valeeval, 2015).

Tahun-tahun pertama usia prasekolah, sekitar dua hingga lima tahun merupakan salah satu tahapan yang penting dalam seluruh tahapan perkembangan dan analisis fungsional anak. Periode ini meletakkan dasar struktur perilaku 
yang kompleks dan dibentuk di dalam kehidupan seorang anak (Erikson, 1950). Hal ini mengindikasikan pentingnya pembiasaan dan stimulasi psikososial anak. Perkembangan anak di Kota Medan untuk berkomunikasi sangat rendah. Rendahnya kemampuan komunikasi anak di Kota Medan disebabkan anak kurang mendapatkan stimulasi bahasa dan sosial dari ibu disebabkan oleh banyak waktu yang dihabiskan anak dengan menonton televisi di rumahnya. Meskipun demikian perkembangan anak untuk menolong dirinya sendiri berpakaian sudah cukup baik.

Temuan berbeda ditemukan pada hasil penelitian Permatasari dan Hastuti (2013) di Kampung Adat Urug, Bogor yang menunjukkan bahwa hanya setengah responden penelitian yang mampu menolong dirinya sendiri untuk berpakaian. Hal ini menunjukkan bahwa kemampuan anak di Kota Medan untuk memakai pakaiannya sendiri sudah cukup baik dibandingkan daerah pedesaan. Tingkat perkembangan sosial anak yang tinggi lebih banyak ditemukan di daerah tengah kota dibandingkan daerah pinggiran. Hal yang sama ditemukan pada hasil penelitian Hastuti, Fiernanti, dan Guhardja (2011) di Kota Bogor juga menunjukkan bahwa anak yang tinggal di daerah pedesaan memiliki total perkembangan sosial yang lebih rendah dibandingkan yang tinggal di daerah perkotaan.

Berdasarkan hasil uji pengaruh usia orang tua saat menikah (usia menikah suami dan istri) dan tingkat pendidikan orang tua (lama pendidikan suami dan istri), kesiapan menjadi orang tua, serta pola asuh psikososial memiliki pengaruh langsung positif yang signifikan terhadap perkembangan sosial anak. Hal ini menunjukkan bahwa apabila pasangan suami dan istri menikah dengan usia yang lebih tua/matang maka akan memiliki pengetahuan, kemampuan, dan pendidikan yang lebih baik serta dapat mempersiapkan dirinya untuk menjadi orang tua, maka akan meningkatkan perkembangan sosial khususnya dalam kemandirian. Menurut Bradley dan Caldwell (1986), pemberian stimulasi yang memadai bagi anak akan membuat anak tumbuh dan berkembang secara optimal.

Tingkah laku dan praktek pengasuhan yang dilakukan oleh pengasuh (ayah, ibu, saudara kandung, kakek, nenek dan kerabat lainnya) dalam memberikan kebutuhan makan, menjaga kesehatan, memberikan stimulasi, dukungan sosial dan lain-lain perlu untuk pertumbuhan dan perkembangan anak yang sehat. Termasuk juga perilaku seperti sikap, nikai, minat dan kepercayaan yang diajarkan pada anak mellui proses pengasuhan dan penidiikan sepanjang perkembangan hidupnya (Engle, Menon \& Haddad, 1997). Anak yang mendapat stimulus psikososial maka perkembangan anak khususnya tingkat perkembangan sosial anak akan lebih baik. Penelitian ini sejalan dengan Kitano et al. (2016) dan Tsania, Sunarti, dan Krisnatuti (2015) yang menunjukkan usia menikah ibu yang semakin tinggi akan mampu memberikan pola asuh yang lebih baik dibandingkan usia ibu yang lebih muda.

Hasil penelitian Augustine et al. (2015) juga diketahui bahwa tingkat pendidikan ibu berpengaruh positif terhadap kemampuan berbahasa dan intelektualnya. Semakin matang usia dan tingkat pendidikan ibu yang tinggi akan meningkatkan kemampuan kognitif dan sosial anak di pre-school. Kemampuan sosial anak salah satunya adalah kemampuan untuk menolong dirinya sendiri yang merupakan bagian dari perkembangan sosial. Hasil penelitian Prado (2016), menunjukkan bahwa keterlambatan pertumbuhan, perkembangan motorik dan sosial diri dari lahir hingga 18 bulan berhubungan dengan stimulasi yang diberikan atau ibu yang tidak menerima suplemen kesehatan. Hal ini menunjukkan bahwa semakin baik kesehatan dan stimulasi yang diberikan ibu maka pertumbuhan, perkembangan motorik dan sosial diri anak juga semakin baik. Riset menyatakan bahwa, anak membangun kerangka kerja mental yang kompleks dan skema sosial. Hal ini akan menentukan sikap, keyakinan, dan tanggapan seorang anak terhadap orang-orang yang dia temui dalam kehidupannya. Peta kognitif ini terdiri dari berbagai stereotipe sosial, sifat pribadi, serta perilaku khas dalam situasi sosial (Nurmalitasari, 2015).

Hasil uji pengaruh menunjukkan bahwa tingkat pendidikan (ayah dan ibu) berpengaruh positif terhadap kesiapan menjadi orang tua. Hal ini sesuai dengan hasil penelitian Ghalili et al. (2012), yang menyatakan bahwa semakin tinggi umur dan tingkat pendidikan orang tua maka kesiapan menikahnya semakin baik. Kesiapan menikah terutama pada kesiapan finansial dan moral (suami dan istri). Pentingnya mempersiapkan finansial dan moral/emosi berhubungan dengan kematangan emosi dan usia ibu saat memiliki anak (Brisbane, 2010). Hasil penelitian Black et al. (2016) menyatakan bahwa seorang ibu yang melahirkan anak pertama kali berisiko lima persen lebih tinggi menjadi obesitas, tujuh 
persen kali lebih tinggi meningkatkan tekanan darah dan tiga persen kali lebih rendah kondisi fisik dan juga kesehatan mentalnya. Penyebabnya adalah ibu belum mampu mengontrol emosi saat mengasuh anak dan tidak memiliki waktu untuk dapat melakukan olahraga. Saat kelahiran anak pertama ibu merasakan kebahagiaan yang tinggi namun tidak beriringan dengan menejemen stress yang dialaminya. Hal ini mengindikasikan pentingnya persiapan ibu untuk menjadi orangtua.

Ibu yang telah siap secara mental berhubungan dengan perkembangan sosial anak (Yousafzai, 2016). Kesiapan ibu (kesiapan emosi) untuk menjadi orangtua berhubungan signifikan dengan perkembangan sosial anak, khususnya dalam perilaku sosial anak. Anak yang diasuh oleh ibu yang memiliki tingkat emosi yang baik akan membuat anak lebih nyaman dan mudah menerima stimulasi psikososial. lbu akan lebih cenderung memberikan afeksi dan kedekatan yang lebih dalam saat memberikan pengasuhan.

Karakteristik keluarga (pendapatan perkapita, usia orang tua, dan besar keluarga) tidak memiliki pengaruh terhadap perkembangan sosial anak. Hal ini sejalan dengan hasil penelitian sebelumnya, bahwa status sosial ekonomi keluarga tidak memiliki pengaruh yang signifikan terhadap perkembangan sosial anak (Singh, Rai, \& Singh, 2012; Latifah, Hastuti, \& Latifah, 2010; Hastuti, 2009; Lestari, Hidayah, \& Karini, 2006). Perkembangan sosial anak dalam hal kemandirian lebih banyak dipengaruhi oleh tingkat pendidikan ibu dan pola asuh psikososial. Hasil penelitian Hastuti (2009) dan juga menunjukkan hal yang sama bahwa perkembangan sosial anak dipengaruhi oleh pengasuhan psikososial yang diberikan ibu. Pola pengasuhan juga berhubungan dengan perilaku sosial anak untuk berinteraksi dengan orang lain. Semakin baik pemberian pola asuh positif kepada anak maka akan meningkatkan perilaku positif sosial anak dibandingkan dengan pemberian pengasuhan yang kasar dan cenderung memaksa (Roopnarine, 2014).

\section{SIMPULAN DAN SARAN}

Rata-rata usia menikah istri dan suami tergolong dewasa muda dengan tingkat pendidikan orang tua 11 tahun. Secara keseluruhan kesiapan menjadi orang tua termasuk kategori tinggi pada dimensi kesiapan emosi, fisik dan kestabilan hubungan, tetapi dimensi kesiapan finansial tergolong rendah dan dimensi sosial serta menejemen tergolong sedang. Rerata pola asuh psikososial terkategori rendah dan hampir sebagian besar anak memiliki tingkat perkembangan sosial tergolong rendah. Faktor yang berpengaruh signifikan positif terhadap perkembangan sosial anak adalah usia orang tua saat menikah, tingkat pendidikan orang tua, kesiapan menjadi orang tua dan pola asuh psikososial.

Sebaiknya meningkatkan pengetahuan dan keterampilan perempuan di Kota Medan dengan menguatkan kembali program GenRe (Generasi Remaja) untuk menyiapkan dirinya menjadi orang tua. Bagi keluarga dan pemerintah daerah untuk bisa meningkatkan usia perempuan dan menikahkan anak saat usianya sudah matang (perpemuan $>21$ tahun dan laki-laki >25 tahun). Memasukkan pembelajaran untuk mempersiapkan diri menjadi orang tua pada kurikulum SMP dan SMA, untuk mempersiapkan emosi, moral, dan kemampuan menejemen sebelum menjadi orang tua. Sebaiknya perempuan dan laki-laki didorong untuk menyelesaikan sekolah ditingkat Sekolah Menengah Atas (SMA) atau hingga perguruan tinggi. Selain itu, Posyandu dan perguruan tinggi Kota Medan diharapkan memberikan pengetahuan dan informasi melalui penyuluhan secara berkala tentang kehamilan, merawat dan mengasuh anak sesuai tahapan perkembangannya, memiliki kesadaran pentingnya sarana dan prasarana stimulasi anak untuk meningkatkan perkembangan sosial anak.

\section{DAFTAR PUSTAKA}

Ashrafun, L. (2016). Correlates of age at first birth among the slum dwellers in Sylhet, Bangladesh. Chinese Journal of Population Resources and Environment, 14(1), 53-57. doi: 10.1080/10042857.2016.1138742.

Augustine, Jennifer, M., Prickett, K. C., Kendig, S. M., \& Crosnoe R. (2015). Maternal education and the link between birth timing and children's school readiness. Journal of Social Science Quartelty, 10, 970-984. doi: 10.1111/ssqu.12150.

Badgar S. 2005. Ready or not? Perceptioms of marital readiness among emerging adults [Thesis]. Brigham Young University.

Biktagiroval GF, Valeeval RA. 2015. Formation of University Students Readiness for Parenthood. [Artikel] Review of 
European Studies 7(4), 93-97. doi: 10.5539/res.v7n4p93.

Black et al. (2016). Growth and development among infants and preschoolers in rural India: economic inequities and caregiver protective/promotive factors. International Journal of Behavioral Development, 1-10. doi: $10.1177 / 0165025416644690$.

Bradley, R. H., Caldwell, B. M., Rock, S. L., \& Harris, P. T. (1986). Early home environment and development of competence: findings from the little rock longitudinal study. Children's Environments Quarterly, 3, 10-22.

[BPS Medan] Badan Pusat Statistik. 2016. Kota Medan dalam Angka. BPS Kota Medan. No. 1275.1601

Brisbane, E. H. (2010). The developing child $2^{\text {nd }}$ edition. United States of America, US: McGraw-Hill Education.

Carrol, J. S, Badgaer, S., Willoughby, B. J, Madsen S. D., \& Carolyn M. B. (2009). Ready or not? criteria for marriage readiness among emerging adults. Journal of Adolescent Research, 24, 349-375.

doi: 10.1177/0743558409334253

Doll, E. (1965). Vineland sosial maturity scale. Minnesota, US: Amerika Guidance Service. Inc.

[Dinkes] Dinas Kesehatan. (2015). Stimulasi deteksi dini dan intervensi tumbuh kembang anak (SDDITK) tahun 2014. Medan, ID: Dinkes.

Engle PL, Menon P, Haddad L. (1997). Care and nutrition; concept and measurement. Washington D.C (US). International Food Policy Research Institute (IFPRI).

Erikson, E. H. (1950). Childhood and society. New York, US: Norton.

Ghalili, Z et al. (2012). Marriage readiness criteria among young adults of Isfahan: a quantitave study, interdiscplinary. Journal of Contemporary Research Business, 4(4), 1076-1083.

Ghazali, I. (2015). SEM metode alternatif dengan menggunakan partial least square. Universitas Diponegoro Semarang, ID: Semarang.

Hastuti, D. (2009). Stimulasi psikososial pada anak kelompok bermain dan pengaruhnya pada perkembangan motorik, kognitif, sosial emosi, dan moral/karakter anak. Jurnal IImu Keluarga dan Konsumen, 2(1), 41-56. doi:

http://dx.doi.org/10.24156/jikk.2009.2.1.4 1.

Hastuti, D., Fiernanti, D. Y. I., \& Guhardja, S. (2011). Kualitas lingkungan pengasuhan dan perkembangan sosial emosi anak usia balita di daerah rawan pangan. Jurnal IImu Keluarga dan Konsumen, 4(1), 57-65. doi: http://dx.doi.org/10.24156/jikk.2011.4.1.5 7.

Kitano, Naomi et al. (2016). Combined effects of maternal age and parity on successful initiation of exclusive breastfeeding. Preventive Medicine Japan Reports, 3, 121-126. doi: 10.1016/j.pmedr.2015.12.010

[KEMENKES RI] Kementerian Kesehatan Republik Indonesia. (2013). Laporan hasil riset kesehatan dasar Indonesia tahun 2013. Jakarta (ID): Kemenkes RI.

Latifah, E., Hastuti, D., \& Latifah, M. (2010). Pengaruh pemberian ASI dan stimulasi psikososial terhadap perkembangan sosial emosi anak balita pada keluarga ibu bekerja dan tidak bekerja. Jurnal IImu Keluarga dan Konsumen, 3(1), 35$45 . \quad$ doi: http://dx.doi.org/10.24156/jikk.2010.3.1.3 5.

Lestari, E. D., Hidayah, D., \& Karini, S. M. (2006). Social maturity among obese children in Surakarta, Indonesia. Journal Pediatrica Indonesiana, 46, 174-178.

Nurmalitasari, F. (2015). Perkembangan sosial emosi pada anak usia prasekolah. Buletin Psikologi Fakultas Psikologi Universitas Gadjah Mada, 23, 103-111.

Permatasari, C. L., \& Hastuti, D. (2013). Nilai budaya, pengasuhan penerimaanpenolakan dan perkembangan sosial anak usia 3-5 tahun pada keluarga Kampung Adat Urug, Bogor. Jurnal IImu Keluarga dan Konsumen, 6(2), 91-99. doi:

http://dx.doi.org/10.24156/jikk.2013.6.2.9 1.

Prado et al. (2016). Effects of an intervention on infant growth and development: evidence for different mechanisms at work. Journal of Maternal and Child Nutrition 13(2), 1-6. doi: $10.1111 / \mathrm{mcn} .12314$. 
Puspitawati, H. (2013). Pengantar studi keluarga. Bogor, ID: IPB Press.

Roopnarine, J. L., Krishnakumar, A., Narine, L., Logie, C., \& Lape M. E. (2014). Relationships between parenting practices and preschoolers' social skills in African, Indo, and mixed-ethnic families in Trinidad and Tobago: the mediating role of ethnic socialization. Journal of Cross-Cultural Phsychology, 45(3), 362-380.

Santrock, J. W. (2007). Perkembangan anak. edisi kesebelas jilid I. Jakarta, ID: Erlangga.

Smith et al. 2012. Early breastfeeding experiences of adolescent mothers: a qualitative prospective study. International Breastfeeding Journal, 7, 113. doi: 10.1186/1746-4358-7-13.
Singh, L., Rai, R. K., \& Singh P. K. (2012). Assessing the utilization of maternal and child health care: among married adolescent women: evidence from India. Hournal Biosoc. Sci, 44, 1-26.

Tsania, N., Sunarti, E., \& Krisnatuti, D. (2015). Karakteristik keluarga, kesiapan menikah istri dan perkembangan anak usia 3-5 tahun. Jurnal Ilmu Keluarga dan Konsumen, 8(1), 28-37. doi: http://dx.doi.org/10.24156/jikk.2015.8.1.2 8

Yousafzai et al. 2016. Effects of responsive stimulation and nutrition interventions on children's development and growth at age 4 years in a disadvantaged population in Pakistan: a longitudinal follow-up of a cluster-randomised factorial eff ectiveness trial. [Artikel]. Lancet Glob Health 4, 48-58. doi: 10.1016/S2214-109X(16) 30100-0 